\title{
Animals and Migration: The Dangers and Effects on Globalization
}

\author{
Ehikioya Hilary Osolase \\ 1. B.A. (Honours) History and International Studies (Ambrose Alli University. KM 70 Benin Auchi Road, P. M. \\ B 14, Ekpoma, Edo State. Nigeria) \\ 2. Certificate in English for Higher Studies (Bostonweb College of Technology and Management. Tingkat 2, \\ Menara MBF, Jalan Sultan Ismail. 50250. Wilayah Persekutuan. Kuala Lumpur, Malaysia) \\ 3. Master of Human Resource Development (Universiti Putra Malaysia. Jalan UPM, 43400 Serdang, Selangor, \\ Malaysia)
}

\begin{abstract}
This research paper was inspired by the CoronaVirus Disease (COVID-19) pandemic. How accusations have been directed to the citizens of China for consuming bats which some people believe is the cause of the CoronaVirus Disease (COVID-19) pandemic. An attempt will be made to define and explain the concept of "climate change." This research study will also make attempt to define "migration and globalization." Bird Migration is almost an unknown area that needs more research. Effects of climate change and global warming have led to birds migrating from one axis of the world to another. Therefore, this research study is going to examine how "climate change and global warming" has led to the migration of animals (especially animals with wings) across continents and countries, since they have the ability to migrate for months flying to different axis of the world. In the course of this research study, the supposed origin of CoronaVirus Disease (COVID-19) will also be discussed. Just like humans migrate for one reason or the other, so also animals migrate too. Among the various animals with wings which have the tendency to migrate, this study is going to concentrate on bats. The different species of bats found in Nigeria and China. How some species of bats found in China may be poisonous for human consumption. And that in some communities in Nigeria bats have been in consistent consumption over centuries and it has actually never been a health risk to those who consume these bats. That if it becomes scientifically proven that some species of bats in China are poisonous for human consumption, and therefore the cause of the CoronaVirus Disease (COVID-19) pandemic, then it is no longer safe for citizens of any country to consume bats. This research study will therefore make explanations from the angle that, due to "climate change and global warming" which also causes drought, there is the possibility for the poisonous species of bats from the China axis to migrate to other parts of the world, and therefore mix-up with other non poisonous bats in other countries and continents. That when a migration of this sort happens, which of course will always happen, then it is advisable for the consumption of bats to be totally discouraged globally. To get its materials for research, this research study will access various online platforms. Online platforms such as mainstream media portals and academic journal articles.
\end{abstract}

Keywords: Animals, Migration, Globalization, Bats, COVID-19, Pandemic, Climate Change.

DOI: $10.7176 / F S Q M / 99-03$

Publication date:July $31^{\text {st }} 2020$

1. INTRODUCTION: The introduction to this research study will focus on the definitions of "climate change, migration, and globalization."

Climate Change

Climate change can be defined as the remarkable or outstanding change in the calculation or evaluation for a stretch or broadened time. Climate change occurs when temperatures, rainfall, cloudburst, storm, snow, and rainstorm have great and considerable changes. This happens over different or diverse decades of time, or in some cases longer (National Geographic, Resource Library). Climate change could also be explained as a situation whereby a comprehensive or extensive range of universal occurrence or happenings which are generated or produced by flaming coal, crude oil, or natural gas, which then goes ahead to affix or include very high warmth accompaniment of gases to the terrestrial sphere. These occurrence comprises of the growth and expansion in temperature movement or drift, which can then be related or chronicled by global warming. This also surrounds or encircles changes that can be seen as the rise of sea levels, the Arctic and mountain glaciers worldwide, the movement or repositioning in flowers and plants, and lastly the very highest or ultimate temperature/humidity appearances (Lineman, Do, Kim, \& Joo, 2015).

Migration

Migration can be explained or defined as the movement of humans or animals from one geographical location to another for non-permanent or permanent settlement. When humans or animals migrate, sometimes it is either long or short distances from one country to another, or from one city to another. Sometimes these movements are engaged in either across a political or administrative boundary. Just like humans, animals also have translocating or migratory way of life. When discussing migration, two important terms can be traced or related to it. These are: 
Immigration and Emigration. Immigration is when humans move in to a new place to settle, either temporarily or permanently. Emigration can be defined or explained as when humans move out of their old places to settle in new places (United Nations, Global Issues, Migration).

\section{Globalization}

Globalization can be explained or defined as the process by which humans become fused or joined together to become one central body or single entity. It is the growth and expansion of a global economy that rapidly develops through a desegregated approach, which is wholly noticeable or distinct by free enterprise, free flow of assets (wealth, money, and resources), and the usage of inexpensive or low-priced overseas or external employment merchandise or trade (Farhad \& Mohammad, 2011). Globalization can also be explained as the process by which interconnection or interlinkage and incorporation or merger between humans, corporations, organizations, and governments globally. As the worldwide exchange and relationship grows further, there comes the consistent growth in foreign trade, plans, schemes, goals, value, traditions, culture, mores, and heritage (Peterson Institute For International Economics).

\section{THE EFEFCT OF CLIMATE CHANGE ON MIGRATION OF BIRDS AND ANIMALS}

It is known by researchers that birds and other animals are forced to migrate even earlier than expected, due to the after-effects derived from the consequences of climate change and global warming. For example, a study from the University of Edinburgh which concentrated its research on hundreds of different types and varieties of birds covering about five continents, made a discovery of a situation whereby birds were actually arriving their reproduction and procreation grounds on an average of about one day before time during the summertime. This happened due to climate change which led to a rise in global temperature. What this simply means is that, these birds had to move early away from their previous homesteads to a new habitation during summer time due to the tensed increase in global temperature caused by climate change. These birds change their dwelling due to the rapidly changing temperature at different seasons, and they must have to survive to hunt for food at their new homesteads. The researchers at the University of Edinburgh also discovered that various types of birds travel long and short distances. For example, the swallow and pied flycatcher are able to travel a very long distance to get a new homestead. While the lapwing and pied wagtail type of birds were able to travel short distances in search of greener pastures. These researchers also observed that the British birds called swallows are able to fly a very long distance through western France and over the Pyrenees, moving through eastern corridors of Spain and into Morocco, and beyond the Sahara to spend some time in South Africa during the winter, and this normally occur from September or October. Also, the researchers discovered that the migrating swallow birds are able to travel or fly a distance of 200 (two hundred) miles daily, at a speed of 17-22 miles per hour, and with a highest or topmost soaring speed of $35 \mathrm{mph}$. The researchers at the University of Edinburgh were also able to examine the records of the various types of these migrating birds which goes as far back as 300 years, as they were able to gather information from non-professional or non-specialist supporters or followers, and as well various scientists, which includes records and accounts from 19th-century American naturalist Henry David Thoreau. This research study from the researchers at the University of Edinburgh was, which was also published and made manifest in the Journal of Animal Ecology, and very well supported by the Natural Environment Research Council, was basically done to get more detailed information on how best the research could help scientists and the general society to better know and therefore foretell how various types of migrating birds react to environmental changes caused by climate change at their various reproducing and nurturing grounds (Knomami, 2017). Some scientists also observed that the widespread and universal migration of different types of wildlife to more accommodating, chilly, and cold places and regions, is a threat to the continuous existence of humans. This is due to the fact that some of these wildlife when migrating, carry along with them various diseases. An example of such wildlife are the mosquitoes, as they are able to transfer and pass on malaria to the humans around their new homesteads. And the problem is that the humans around these places may have very low immunity to withstand these diseases (Carrington, 2017). 


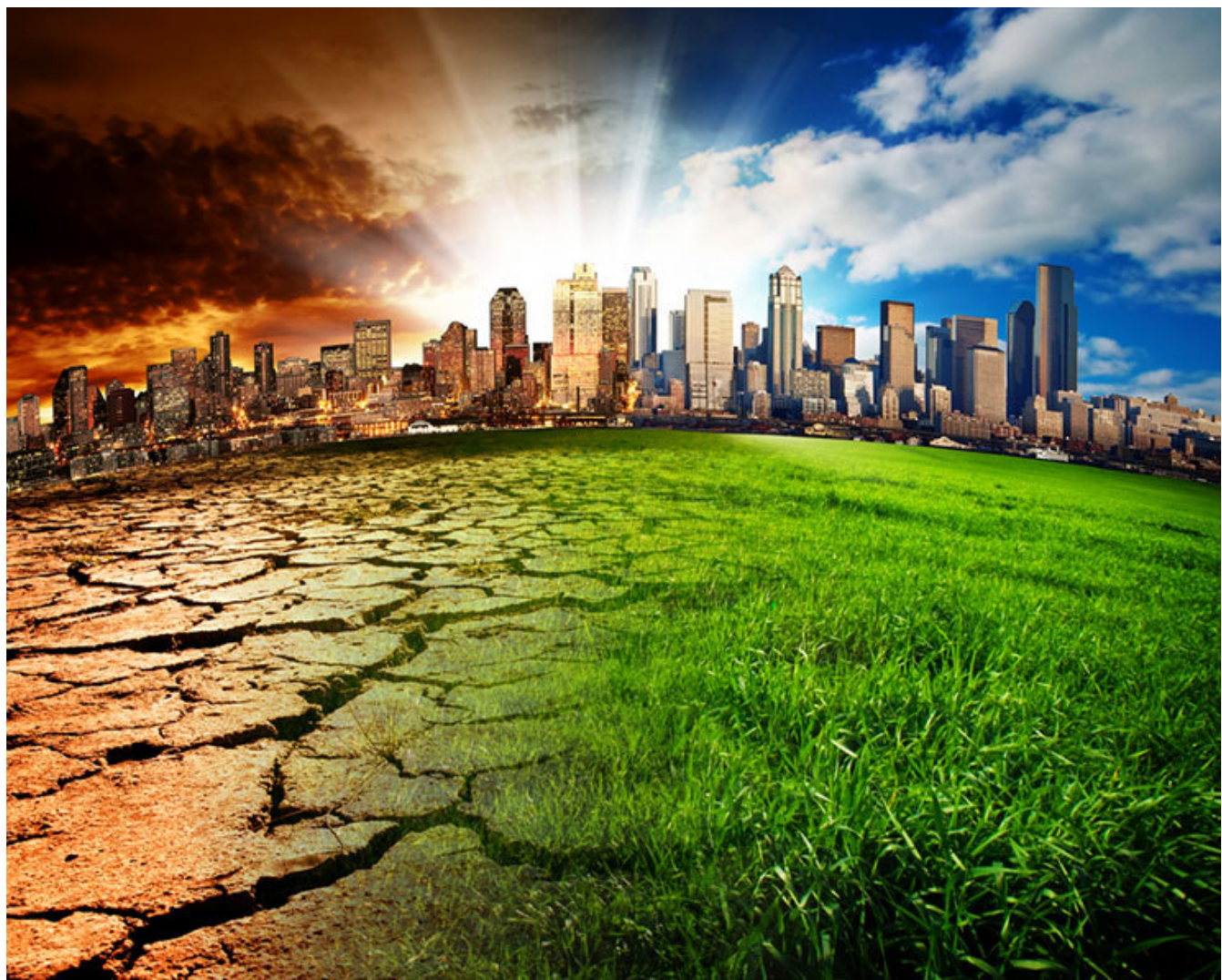

(National Aeronautics \& Space Administration).

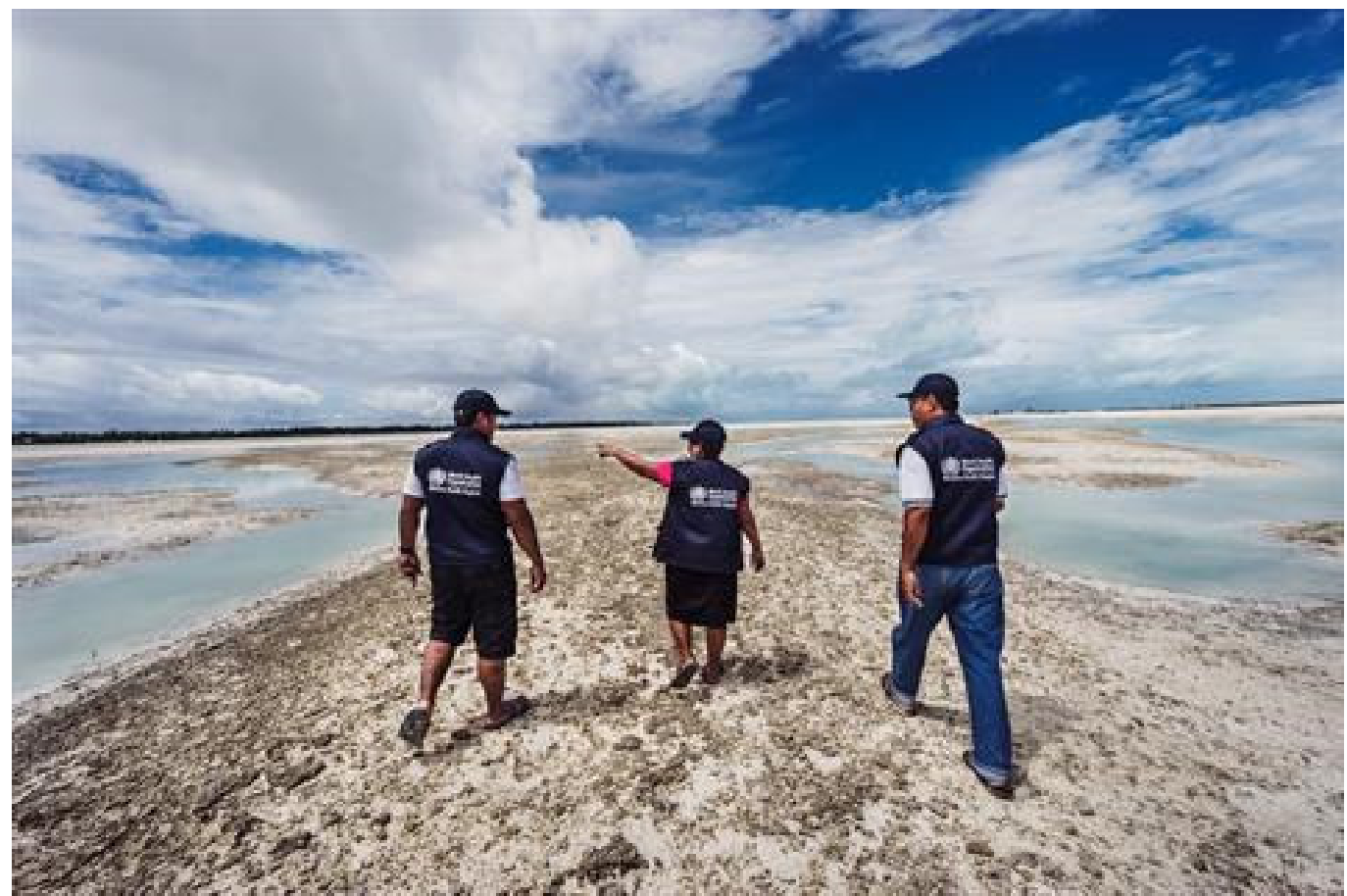

(World Health Organization).

\section{ORIGIN OF CORONAVIRUS DISEASE (COVID-19)}

Citizens across various countries globally believe the COVID-19 pandemic originated from the now globally known Huanan seafood market, which is located in Wuhan, the capital city of China's Hubei Province. They believe that it was from this market that the virus from an animal (bat) first mutated and infected human. Others also believe that the virus may have originated from pangolins, a scurfy and scabrous mammal that has the anteater of an anteater. However, these beliefs have not been authenticated by either researchers or scientists, as it is under 
a study and research process. It is however known among various scientists and researchers that viruses in the nature of coronavirus circulates and exists among various species of animals, and it is easily shared among animals, with a case of a tiger reportedly infected in a zoo in New York. However, scientists and researcher are still the coronavirus more, as some claim that the virus may have actually originated from a bat. But that it may have first come through a go-between wildlife just like the same way another virus from the coronavirus family called SARS did in its 2002 epidemic and upsurge, by first having to horseshoe bats, then on to cat-like civets, before finally moving further to infect humans. However, Dr Michelle Baker who happens to be an immunologist at CSIRO (Commonwealth Scientific and Industrial Research Organization), a scientist and researcher who studies viruses in bats, says that some of the research conducted on the origins of COVID-19 have actually gone the wrong way from what was well known from past studies and researches (Readfearn, 2020). The CoronaVirus Disease (COVID-19) is an extremely communicable and contagious bacterium with viral infection on humans which causes Severe Acute Respiratory Syndrome CoronaVirus 2 (SARS-CoV-2). The scientific investigation relating to the complete set of genes in the cell and organism of the virus, disclosed that SARS-CoV-2 is in a way related to the species or group of organisms of the Severe Acute Respiratory Syndrome (SARS) bat viruses. What this means is that bat could be the feasible chief pool or homestead of these viruses that causes COVID-19. At the moment no antiviral, antibacterial, or therapeutic drugs or vaccine has been medically authorized or validated to be used for the treatment against CoronaVirus Disease (COVID-19). Nevertheless, little and a small number of antibiotics drugs which are very effective against a sizeable and substantial types of organisms have been assessed and analyzed for scientific and clinical experimentals against CoronaVirus Disease (COVID-19), which have led to clinical recoveries of infected humans around various countries in the world (Muhammad, Adnan, Suliman, Abeer, Nadia, \& Rabeea, 2020).

\section{CONSUMPTION OF BAT MEAT IN CHINA}

It is no longer a thing of hearsay that there is the much consumption of bat and other wildlife meat in China. However, with the outbreak of the CoronaVirus Disease pandemic it became more popular and continue to resonate further globally. Most people across the world believe that the COVID-19 is a virus infection gotten from bat meat. The COVID-19 pandemic was first discovered in Wuhan, China. With this believe, so many people across the world believe that China must therefore device a strategy in putting to stop among its citizens the consumption of bat and other wildlife meat. That in been able to do this, a future outbreak of this type will be averted. This believe has led to the persecution, intimidation, and molestation of various Chinese and Asians across America who are regarded as Asian-Americans. This has also led to the destruction and wrecking of various Chinese and AsianAmerican businesses (Shen-Berro, 2020). With the banning in China by the Chinese government (through the National People's Congress) on the consumption of wild animals like bats and snakes, due to the coronavirus outbreak which began around late December in Wuhan central Chinese markets, there is still the attempt by Chinese officials and citizens to indulge in the very profitable and high-paying business of exporting wildlife meat to other countries, as officials of the finance ministry offered new motivation and stimulus to traders in the industry. Measures taken are such as tax rebates, in which the traders are exempted from paying any tax to the government while shipping out these animal products such as bats, snakes, and turtles. This is done to entice traders in the industry. The reasons for the global outcry on the continued consumption of these wildlife meat such as bats by citizens of China, and an attempt by the Chinese officials and its citizens to import these wildlife are due to the health risks it poses to humanity. However, the new tax free system and strategy by the Chinese officials have been brought to the attention of the United States Congress. The US Congressional Research Service which works for the US Congress and happens to be neutral and disinterested in party politics, came up with the assertion that the struggle and striving by the Chinese government to trade in the meat of wild animals overseas, while having same meat of wild animals outlawed and banned at home in China, will pose a risk to the spread of coronavirus disease to global markets (O’Keeffe \& Xiao, 2020). 


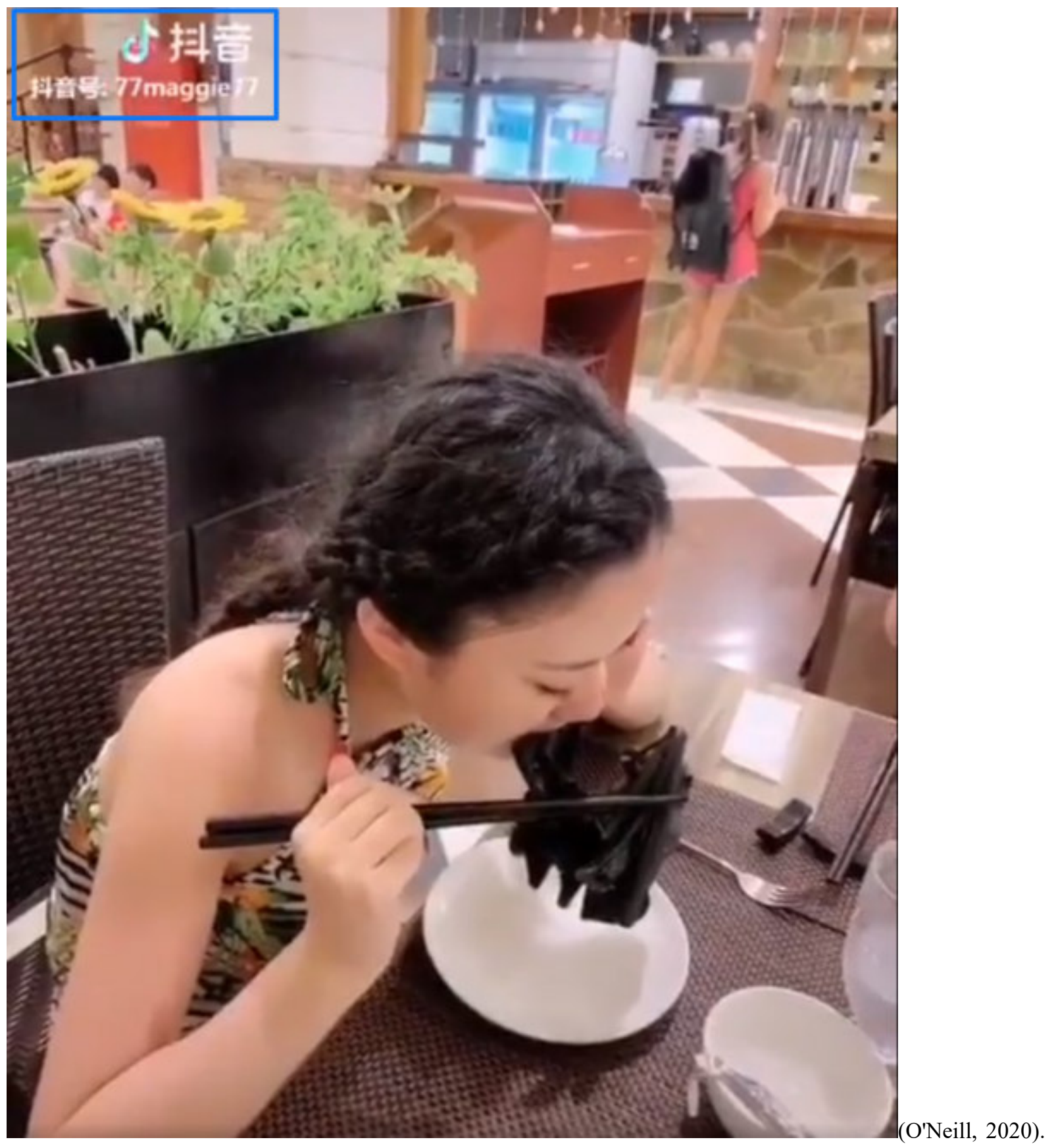




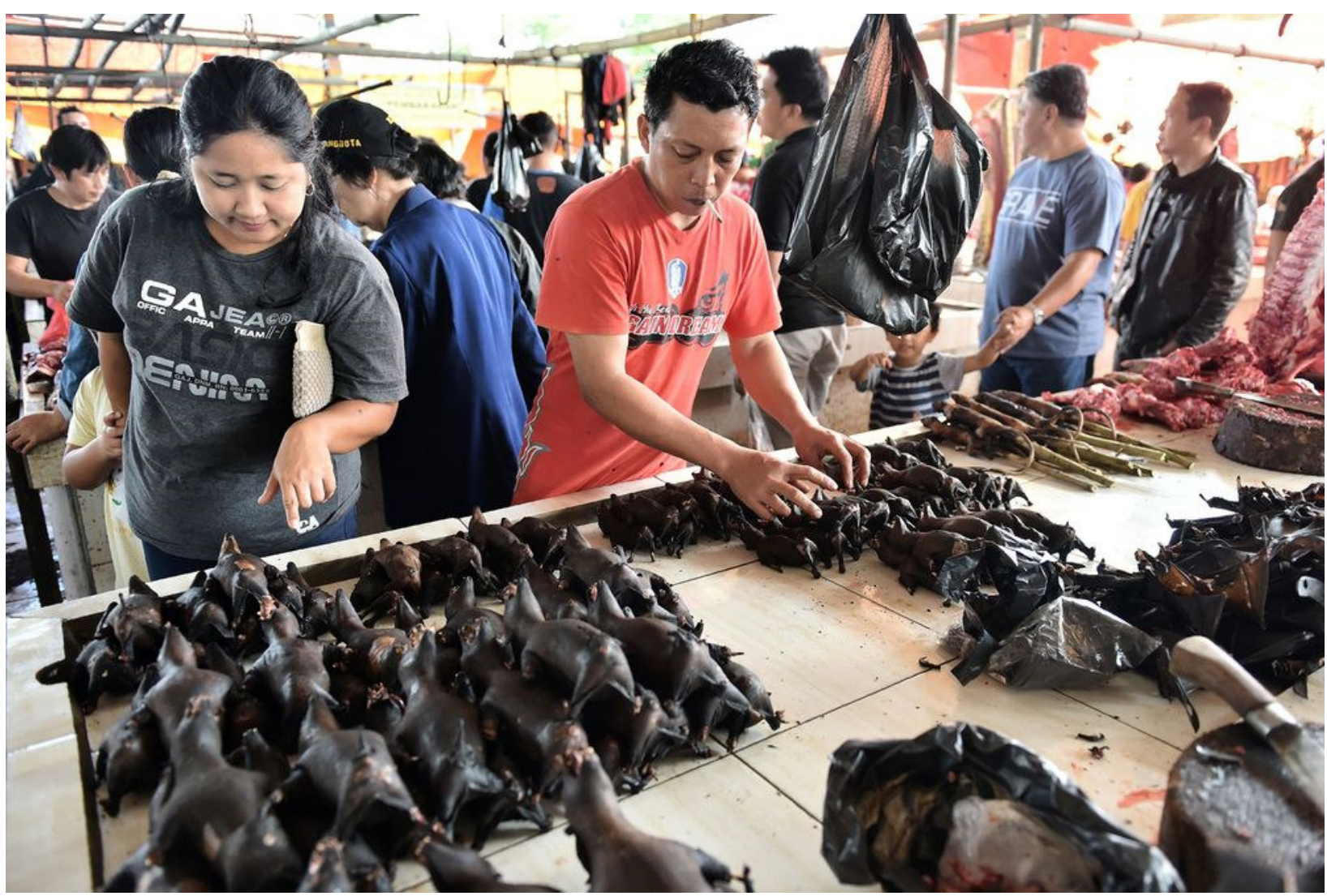

(Google Image)

\section{CONSUMPTION OF BAT AND BUSHMEAT IN NIGERIA AND OTHER AFRICAN COUNTRIES}

Before the outbreak of the Ebola Virus in 2014, the Nigeria bushmeat industry was a highly profitable sector and was able to finance the activities of so many homes across Nigeria and in some other African countries. The outbreak of the Ebola Virus in 2014 affected the meat industry sector as so many people were afraid to eat these meats because it was believed that the Ebola Virus infected humans through these bushmeat. Few years after the outbreak, business returned and everything becomes normal. It is a belief in Africa that some species of fruit bats are natural carriers of the Ebola Virus, as bats who are infected are suspected to transfer these viruses to humans directly, or through other different species of bushmeat. However, over the centuries Nigerians (mostly from the rural communities) and some other African countries have always been a consumer of bat meats and other bushmeat, and so really do not believe that these wildlife animals are carriers of the COVID-19 disease or the Ebola Virus (Mohamed, 2018). Among the Congolese people there is still a very high and cherished consumption of bat meats in spite of several forewarning and red flag by health officials against its continuous consumption. Various homes and restaurants are still in the habit of eating bat meat, and among the people of Lingala language its localized name is "ngembo." As explained by one among the numerous consumers, bat meat delicacy is not difficult to prepare for eating. And to get the parts of the bat meat it is always available at the market from prices ranging between $\$ 1$ to $\$ 2.5$. Though the price of bat meat in Congo is considered very cheap and the people very much appreciate the it, however there is a fierce debate on whether to stop or continue to consume bat meat, as some people see it as having a high nutrient, while others see it as a homestead for various viruses that are very harmful to humans (Oduor \& Pioth, 2019). 

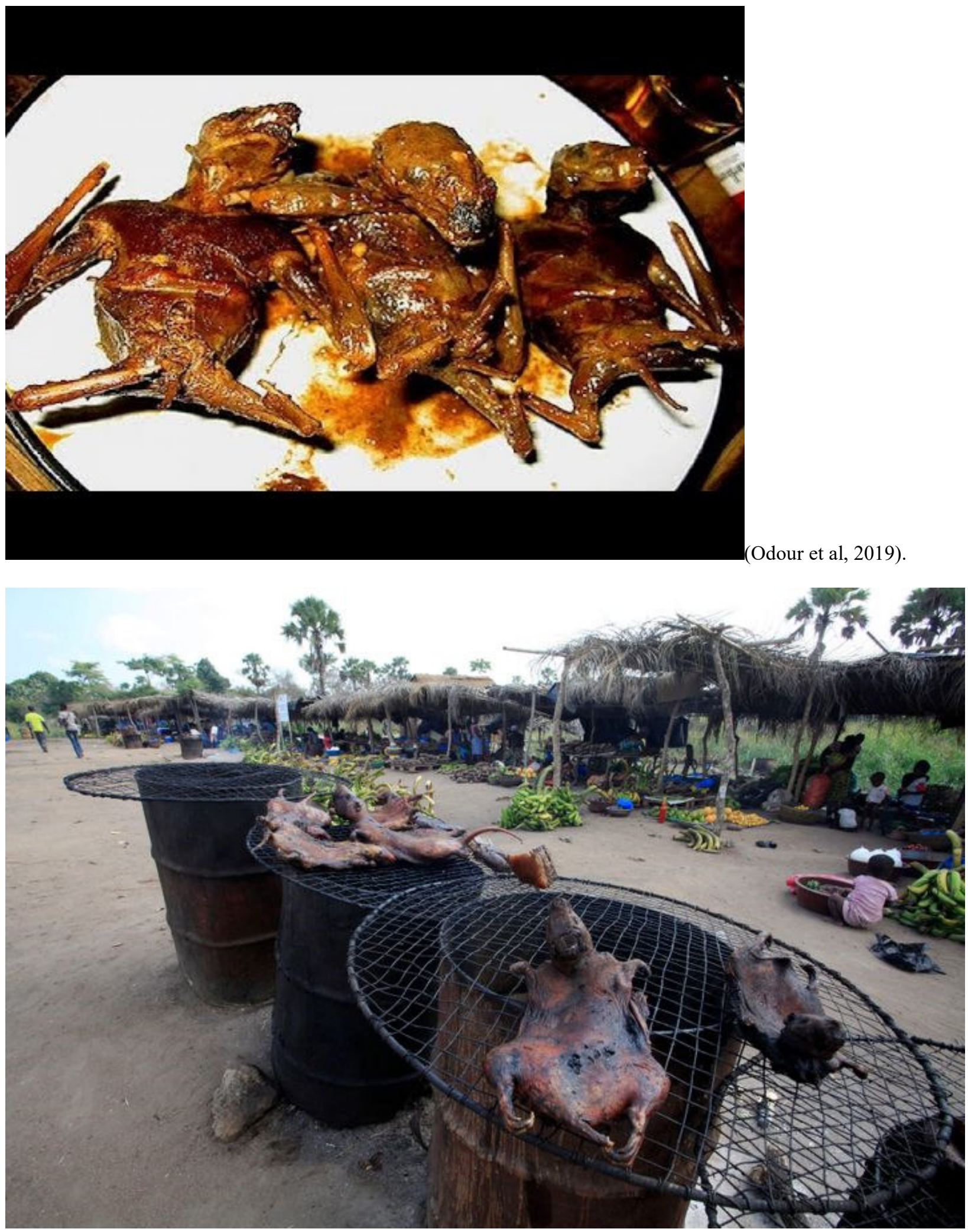

(Google Image).

\section{CONCLUSION}

This research study is not a finalization of the topic of research discourse, but just a contribution to the body of knowledge, as it is a continuous research process by other researchers. However, the concluding aspect of this research study will concentrate on how migration of various animals (with more emphasis on bats) poses a serious threat to humanity, as it relates to the continuous consumption of bat meat and bush meat across various countries. 
This research study has been able to identify the fact that various species of bats and other wildlife animals migrate from their homestead to other territories due to climate change and change in temperatures. It is a known fact that just as humans migrate to other climes and in search of greener pastures, so also birds and other wildlife animals migrate too. Humans also migrate due to climate or temperature change from their homestead to other territories, chiefly among which is drought caused by climate change, as humans migrate in search of territories where they can live a suitable life with an abundance of water. These are also one of the chief reasons why birds migrate as well. However, as these birds migrate to other territories, they carry along with them various viruses which are then transmitted to either other birds or wildlife animals in their new territories or even humans. It is on this basis that humans should be encouraged and advised to stop the consumption of some of the species of these birds and other wildlife animals, chiefly among which is bat meat. Governments of various countries must therefore put forward laws which must stop the sale and consumption of these animals locally. Various government agencies across countries must therefore engage in sensitizations to discourage local consumptions, since the citizens at the local communities can easily have access to these animals through the forests located around them. Also, laws banning the importation or exportation of these animals must be applied, otherwise humanity may in no distance time experience more devastating viruses and diseases which may be worse than CoronaVirus Disease (COVID19). In putting these laws to effect, transparency must also be applied in other that the corrupt ones amongst the citizens do not use their closeness to official powers to sideline the laws by either exporting or importing the meat of these various animals that are natural carriers of these viruses.

\section{References}

Carrington, D. (2017, March 30). Climate Change: Global Reshuffle Of Wildlife Will Have Huge Impacts On Humanity. The Guardian International Edition. https://www.theguardian.com/environment/2017/mar/30/climate-change-global-reshuffle-of-wildlife-willhave-huge-impacts-on-humanity

Climate Change Image. National Aeronautics and Space Administration. https://www.nasa.gov/

Climate Change. National Geographic. Resource Library, Encyclopedic Entry. https://www.nationalgeographic.org/encyclopedia/climate-change/

Climate Change Image. World Health Organization. https://www.who.int/

Farhad, N. H. A. I, \& Mohammad, R. N. (2011). Globalization and Challenges; What are the globalization's contemporary issues? International Journal of Humanities and Social Science. 1(6).

Knomami, N. (2017, Jan 8). Climate Change Is Driving Birds to Migrate Early. Climate Central. The Guardian. https://www.climatecentral.org/news/climate-change-driving-birds-migrate-early-21031

Lineman, M., Do, Y., Kim, J. Y., \& Joo, G. J. (2015). Talking about Climate Change and Global Warming. PLoS ONE. 10(9). https://journals.plos.org/plosone/article?id=10.1371/journal.pone.0138996

Migration. Global Issues. United Nations. https://www.un.org/en/sections/issues-depth/migration/index.html

Mohamed, H. (2018, May 31). Nigeria Bushmeat Industry Rebounds After Ebola Virus Outbreak. Aljazeera News International. https:/www.aljazeera.com/indepth/features/nigeria-bushmeat-industry-rebounds-ebolaoutbreak-180329072812588.html

Muhammad, A. S., Adnan, S., Suliman, K., Abeer, K., Nadia, B., \& Rabeea S (2020). COVID-19 Infection: Origin, Transmission, And Characteristics Of Human CoronaViruses. Journal of Advanced Research. ScienceDirect. 24. 91-98. https://www.sciencedirect.com/science/article/pii/S2090123220300540

Odour, M. \& Pioth, R. (2019, Oct 14). Congolese Dismiss Dangers Of Consuming Bat Meat. AfricaNews. https://www.africanews.com/2019/10/14/defiant-over-dangers-of-consuming-bat-meat-congolese-stillcarried-away-by-its//

Odour et al (2019).

O’Keeffe, K. \& Xiao, E. (2020, April 12). Amid Coronavirus Pandemic, China Bans Domestic Trade of Wild Animals But Offers Tax Breaks for Exports. The Wall Street Journal. https://www.wsj.com/articles/amidcoronavirus-pandemic-china-bans-domestic-trade-of-wild-animals-but-offers-tax-breaks-for-exports$11586683800 ? \mathrm{mod}=\mathrm{hp}$ lead_pos5

O’Neill, M. (2020, Jan 27). Confronting Photos Show Influencer Eating Bat Soup. The Chronicle. https://www.thechronicle.com.au/news/truth-about-influencers-bat-soup-video/3930404/

Readfearn, G. (2020, April 15). How Did CoronaVirus Start And Where Did It Come From? Was It Really Wuhan's Animal Market? The Guardian International Edition. https://www.theguardian.com/world/2020/apr/15/how-did-the-coronavirus-start-where-did-it-come-fromhow-did-it-spread-humans-was-it-really-bats-pangolins-wuhan-animal-market

Shen-Berro, J. (2020, March 18). Sen. Cornyn: China To Blame For Coronavirus Because People Eat Bats. NBC News. https://www.nbcnews.com/news/asian-america/sen-cornyn-china-blame-coronavirus-because-peopleeat-bats-n1163431

What Is Globalization? And How Has The Global Economy Shaped The United States? Peterson Institute For 
International Economic. https://www.piie.com/microsites/globalization/what-is-globalization Wildlife Meat Market in China. Google Image. https://www.google.com/imghp?hl=en Wildlife Meat Market in Nigeria. Google Image. https://www.google.com/imghp?hl=en

\section{Biography of Corresponding Author}

The author of this academic paper attended Ambrose Alli University, Ekpoma. Edo State, Nigeria, and graduated with a Bachelor of Arts (Honours) degree in History and International Studies in 2005. Thereafter, he also acquired a one year Certificate in English for Higher Studies in 2010 at BostonWeb College of Technology and Management, Kuala Lumpur, Malaysia. The author also has to his credit a Master Degree of Human Resource Development from Universiti Putra Malaysia (UPM), Serdang, Selangor, Malaysia. The corresponding author have been admitted for a $\mathrm{PhD}$ (Doctor of Philosophy) programme. The PhD programme in Human Resource Development (HRD) will commence by March 2021.

The author also has other (four) academic research papers to his credit, which are listed below:

1. Adekanye, T. B., Oladipo, K. S., Mohammed, A., Adekunle, S. O., Osolase, E. H., \& Nwosu, L. N. (2013). Perceptions of Secondary School Female Students on the Introduction of (MVC) in Improving English Vocabulary Skills. Global Institute for Research \& Education (GIFRE), Global Journal of Commerce and Management Perspective, G.J.C.M.P, 2(3), 1-6.

2. Osolase, E. H. (2013). International Students Perception on Diversity Management at an Academic Department: A Case of the Department of Professional Development and Continuing Education, Universiti Putra Malaysia. Global Institute for Research \& Education (GIFRE), Global Journal of Commerce and Management Perspective, G.J.C.M.P, 2(5), 1-7.

3. Osolase, E. H. (2014). Ethnicism/Ethnocentrism in Nigeria's Political and Historical Space. 1999-2011. Global Institute for Research and Education (GIFRE), Global Journal of Interdisciplinary Social Sciences, GJISS, 3(2), 80-89.

4. Osolase, E. H. (2017). Comparing and Contrasting the Challenges and Successes of ECOWAS as it also Relates to the Challenges and Successes of ASEAN (Association of South-East Asian Nations). Historical Research Letter, International Institute for Scientific and Technical Education, 43, 1-22. 